\title{
LAS CARTAS MADRILEÑAS DE ALFONSO REYES A JULIO TORRI
}

\author{
POR \\ SERGE IVAN ZAÏTZEFF \\ The University of Calgary, Canada
}

Las nuevas cartas inéditas de Alfonso Reyes (1889-1959) dirigidas a Julio Torri (1889-1970) — no incluidas en Diálogo de los libros ${ }^{1}$ - permiten echar un poco más de luz sobre la entrañable amistad que unió a estos dos escritores durante más de cincuenta años. Salvo seis o siete cartas que remontan a 1910-11, el epistolario Reyes-Torri se inicia con la partida de aquél en 1913. La primera época de este intercambio epistolar es corta y corresponde a la estancia de don Alfonso en París entre 1913 y $1914^{2}$, mientras que la segunda abarca un período de diez años de intensa actividad intelectual en Madrid.

Si bien es cierto que ya a partir de octubre de 1914 Reyes se encuentra en la capital española después de un mes en San Sebastián, las primeras cartas entre Reyes y Torri que se han conservado datan de 1916. De hecho, después de abril de 1914 surge un inexplicable silencio entre los dos. Torri se queja con Pedro Henríquez Ureña de «la infame conducta de Alfonso» (14 de mayo de 1914) y de que sus cartas «ya no nos llegan desde hace mucho» (9 de septiembre de 1914) ${ }^{3}$. Todavía hasta mayo de 1916, Torri le pide al dominicano noticias de su compañero regiomontano, así como su dirección. Por su parte, don Alfonso, ya en la primera carta

${ }^{1}$ Julio Torri, Diálogo de los libros. Compilación de Serge I. Zaïtzeff (México: Fondo de Cultura Económica, 1980).

2 Véase nuestro "Las cartas parisienses de Alfonso Reyes a Julio Torri», México en el Arte, núm. 9 (verano de 1985), pp. 25-31.

${ }^{3}$ Carta reproducida en nuestro El arte de Julio Torri (México: Editorial Oasis, 1983), pp. 124-125. Sobre las relaciones entre Torri y el maestro dominicano véanse también nuestros «La amistad de Julio Torri con Pedro Henríquez Ureña», Aula (Revista General de la Universidad Pedro Henríquez Ureña), núm. 47 (octubrenoviembre-diciembre de 1983), pp. 59-69, y «Otras cartas de Pedro Henríquez Ureña a Julio Torri», Sábado (Suplemento de Uno más Uno), 12 de enero de 1985, pp. 4-5. 
que le manda a don Pedro desde España (San Sebastián, 19 de septiembre de 1914), le dice: «¿No sabes si Acevedo [Jesús T.] habrá asesinado a Torri? Por más que le pregunto por él, no me da noticias suyas» ${ }^{4}$. Se mantiene este silencio hasta el 11 de noviembre de 1916, cuando Reyes recibe lo que parece ser la primera carta de Torri (con fecha de 21 de octubre) en España. Así se lo comunica a Henríquez Ureña ese mismo día: «iAl fin! Hoy recibí carta de Julio Torri el deseado» ${ }^{5}$. Reyes, quien había perdido casi toda esperanza de tener noticias no solamente de Torri, sino de sus otros amigos mexicanos, le escribe largamente el 15 de noviembre para así dar comienzo a lo que él mismo llama «esta segunda época epistolar» ${ }^{6}$.

Esta primera carta (reproducida en Diálogo de los libros) ofrece sobre todo abundantes detalles sobre las actividades de Reyes después de tan larga interrupción en el diálogo con su querido corresponsal. En particular evoca con sincera gratitud la generosa ayuda de sus amigos españoles, a quienes debe «el vivir con cierto decoro y con decente pobreza» ${ }^{7}$. Se recordará que sus primeros años en Madrid fueron muy difíciles y que sólo vivía de la pluma. Le comunica a Torri que se ha dedicado a publicar notas «sin importancia ni elegancia» en la Revue Hispanique de París, así como numerosos artículos eruditos en la Revista de Filología Española, publicación que se distingue por su «severidad brutal». Son trabajos - como dice Reyes-- en los cuales éste no es más que «una máquina de técnica literario-histórica», sin que aparezca lo personal. Luego se refiere ampliamente a sus responsabilidades en la importante sección de filología del Centro de Estudios Históricos al lado de Ramón Menéndez Pidal y otros distinguidos especialistas como Tomás Navarro Tomás, Américo Castro, Federico de Onís y Antonio G. Solalinde. Además, Reyes colabora frecuentemente en publicaciones cubanas, argentinas y españolas con toda clase de artículos, inclusive de crítica cinematográfica. Es un período de enorme productividad: «He escrito mucho, mucho, y ya soy otro, siendo aún el que siempre fui» ${ }^{8}$. De hecho, prepara en estos momentos la edición de dos obras de Ruiz de Alarcón para La Lectura, así como diversas antologías para el Centro de Estudios Históricos; además ha terminado de editar el Peregrino de Lope de Vega para la casa Nelson y de traducir la

${ }^{4}$ Pedro Henríquez Ureña y Alfonso Reyes, Epistolario intimo (1906-1946). Recopilación de Juan Jacobo de Lara (Santo Domingo, R. D.: Universidad Nacional Pedro Henríquez Ureña, 1981), II, p. 55.

${ }^{5}$ Ibíd., III, p. 23.

- Diálogo de los libros, p. 195.

"Ibíd., p. 196.

'Ibidd., p. 197. 
Ortodoxia de Chesterton para Calleja. Y tampoco se ha olvidado «de lo mío, de lo tuyo, de lo nuestro», que pronto le mandará (El suicida). Son tantos los compromisos que don Alfonso ha contraído, que aun Manuela, su esposa, participa activamente en esa labor corrigiendo pruebas, cotejando ediciones viejas y escribiendo a veces sus crónicas dominicales. Pero, con todo, Reyes se siente íntimamente ligado a su pasado y a sus compañeros ateneístas, pues "yo no puedo olvidarme de lo mejor de mi vida» ${ }^{9}$. Quiere tener noticias de sus amigos mexicanos, quiere colaborar con ellos, quiere recibir libros (los de la colección Cvltvra, que Julio Torri dirigía junto con Agustín Loera y Chávez) y sobre todo quiere que su amigo venga «a pasar hambres y a vivir peligrosamente».

Al recibir esta carta, Torri no espera y le contesta en seguida (el $13 \mathrm{de}$ diciembre de 1916$)^{10}$. Le causa mucha alegría ver que, pese al prolongado silencio, su compañero sigue siendo su «generoso y valiente Alfonso de siempre», y le corresponde a su vez con unas «divagaciones autobiográficas» llenas de deliciosas confidencias y chismes literarios. En su respuesta del $1 .^{\circ}$ de marzo de 1917 (inédita) a Torri, «el genial» ${ }^{11}$, Reyes le informa de la aparición de su Visión de Anáhuac con García Monge, quien le pedirá algo a don Julio para «El Convivio». Así nace, gracias al apoyo de Reyes, el libro titulado Ensayos y fantasías, que se publicará en San José de Costa Rica en 1918. En realidad, este tomo no es más que una breve selección del primer libro de Torri, que por esas fechas todavía estaba en prensa. En esta misma carta Reyes alude a la partida del arquitecto Jesús T. Acevedo para El Paso (Texas) después de haber vivido varios años en Madrid y a la presencia de otro amigo mexicano, Pablo Martínez del Río, el que fue director del único número de La Nave (1916). Pero se ve que don Alfonso poco lo frecuenta y que sólo piensa en su querido Julio: «Eres tú quien debía estar por acá, y todas las noches te sueño.» Al final Reyes lo felicita por sus Cuentos de Andersen (1916), primera edición al ctidado del propio Torri en Cvltvra, y le dice: «Venga, pues, tu libro. Tú mismo ven. ¿Qué diablos haces allá?» Por lo visto, el trato fraternal e íntimo de antes no ha sido afectado por los largos lapsos que hubo en su intercambio epistolar.

El epistolario sigue con un par de cartas de Torri que han sido recogidas en Díálogo de los libros. En la del 16 de julio de 1917 es interesante leer que Torri acaba de recibir el manuscrito de los Cartones de

\footnotetext{
${ }^{9}$ Ibid., p. 198.

${ }^{10}$ Las cartas de Julio Torri a Alfonso Reyes se reproducen en Diálogo de los libros.

${ }^{11}$ De una carta de Reyes a Henriquez Ureña (10 de diciembre de 1916), en Epistolario intimo, II, p. 31 .
} 
Madrid para su publicación en Cvltvra, libro que él mismo cuidará. También ya llegó su «admirable» $E l$ suicida y pronto Torri le corresponderá con una novedad: «mi primer libro, mi libro-promesa, mi libro-arrepentimiento-eterno, que se llamará Ensayos y poemas» ${ }^{12}$. E1 24 de agosto de 1917 Torri le comunica a su amigo que ya le mandó los Cartones de Madrid - «libro [que] ha gustado mucho»-, así como su propia obra con suficientes ejemplares para los amigos de Reyes en Madrid. Los deseos de Torri de recibir una larga carta se cumplen por fin con la del 20 de septiembre de 1917 (inédita), la cual atestigua desde el principio el profundo afecto de don Alfonso: «Oh mi querido Julio, mi leal verdadero: Me muero de gusto cuando recibo una carta tuya.» $Y$ luego expresa su inmensa satisfacción con Cartones de Madrid, pese a las inevitables erratas, que ahora Reyes acepta estoicamente; puesto que «la errata es un microbio, no se la puede destruir ni a la temperatura del plomo derretido de la linotipia». Luego de of recerle unas pormenorizadas instrucciones en cómo hacer paquetes, Reyes se refiere a la reciente visita de Pedro Henríquez Ureña, quien fue recibido con sincero entusiasmo por los intelectuales españoles. Durante los dos meses que pasó en Madrid parece que el dominicano - en vez de descansar - trabajó febrilmente con el fin de dejar unas notas para la Revista de Filología Española y gran parte de una antología de poetas americanos (en la cual intervinieron Enrique DíezCanedo y Alfonso Reyes). Además, la presencia de don Pedro dio luz a muchos proyectos de colaboración con su amigo mexicano, en quien volvió a encontrar un espíritu muy afín al suyo. Y desde luego no podía estar ausente de esas conversaciones la figura del que escogió el exilio interior.

Con la salida de Pedro Henríquez Ureña y de Pablo Martínez del Río, don Alfonso vuelve a sentirse solo y nostálgico de su tierra, de «la dulzura de aquel trato" y de la incomparable ciudad de México. Torri está siempre presente en Reyes, quien le está escribiendo unas páginas tituladas La estrella del sur («es la historia de mi declinación hacia el mediodía, mi viaje espiritual desde París a Madrid. Hará época en la historia de nuestra amistad ${ }^{13}$ ) y quien, consciente de la timidez que caracteriza a su compañero, le da valiosos consejos con el propósito de animarlo a publicar, ya que por fin ha salido su primer libro. Aunque ambos amigos tienen la misma edad, es evidente que a menudo Reyes actúa como el maestro, como el estimulador de Torri. Pero éste es sobre todo su más querido amigo por haber sido su «compañero de banco de escuela», y es por este mo-

${ }_{12}$ Diálogo de los libros, p. 204.

${ }^{13}$ Se trata seguramente del texto titulado «Rumbo al sur», fechado en 1918 y luego incorporado a Las vísperas de España (1937). 
tivo que le manda todo lo suyo esperando siempre el gusto de leer las cartas de don Julio, cartas que según Reyes «tanto bien me hacen». Dos días más tarde -el 22 de 'septiembre de 1917- Reyes le envía una lista de las erratas (pocas) que encontró en Cartones de Madrid y expresa su deseo de recibir el prometido libro de Torri, deseo que por fin se cumple el 2 de octubre, como se puede ver en la carta del propio Reyes fechada el 3 de octubre y reproducida en Diálogo de los libros. Esta conocida misiva ofrece unos agudos comentarios acerca de Ensayos y poemas, libro que para Reyes «está escrito de una manera perfecta» ${ }^{14}$. E1 mismo entusiasmo es aparente en las primeras líneas de una carta dirigida a Pedro Henríquez Ureña el 8 de octubre, donde Reyes escribe: «He recibido de México el precioso libro de Julio, que es de oro puro» ${ }^{15}$. Además, nota que Torri tuvo razón en excluir ciertos textos de «humorismo un tanto extravagante», aunque ahora debería aprovecharios, «porque son personalísimos». Sin duda Reyes se refiere aquí a ciertas prosas que fueron rescatadas en Diálogo de los libros y a otras que todavía quedan inéditas ${ }^{16}$.

La próxima carta de Reyes (13 de noviembre) contesta la del «irresistible» Torri escrita en octubre y se recoge en Diálogo de los libros. En esta carta, Reyes recuerda especialmente el paso de don Pedro por Madrid y describe sus propias actividades, las cuales se han vuelto cada vez más numerosas. E1 28 de diciembre Torri le responde, y así concluye el epistolario de 1917. Por lo que se refiere a 1918, ahora tenemos nuevas cartas de Reyes empezando con la del 7 de enero, una respuesta a la carta «llena de íntimo calor» que Torri le escribe "un día claro de noviembre». Por encima de todo se ve que lo que más aprecia Reyes en las epístolas de su amigo son sus confesiones íntimas. Es precisamente esta nota personal la que distingue este epistolario de las demás correspondencias alfonsinas, las cuales tienden a ser mucho más literarias y eruditas. Luego de una carta de Reyes con fecha de 17 de marzo, que no ha sido posible localizar (Torri alude a ella en carta del 13 de mayo), y de dos notas cortas de encargos (3 y 5 de mayo), don Alfonso vuelve a dirigirse a Torri el 28 de julio de 1918 explicándole que no le había contestado antes a su misiva del 13 de mayo porque pensaba que Torri seguramente vendría a Madrid. Nuevamente Reyes le comunica el inmenso placer que experimenta al leer sus cartas: «Tus últimas cartas son las mejores que me has escrito en tu vida, porque al fin has escrito todo lo que tenías dentro.»

${ }^{14}$ Diálogo de los libros, p. 208.

${ }^{15}$ Epistolario intimo, III, p. 60.

:5 Hemos dado a conocer algunas de estas páginas inéditas en nuestro "Inéditos de Julio Torri», Universidad de México, XL, núms. 409-410 (febrero-marzo de 1985), pp. $29-34$. 
Es interesante notar que ya para 1918 Torri -según lo observa Reyes - gozaba de cierto prestigio entre los intelectuales españoles de mayor relevancia, especialmente Juan Ramón Jiménez y Enrique Díez-Canedo ${ }^{17}$. En esta misma carta del 28 de julio Reyes caracteriza la presencia de Torri en estos términos: «Aquí los que valen te conocen, por ti y por mí: más por ti que por mí. Y te aman, menos que yo, porque en eso ¿quién me igualaría?» En estos momentos de melancolía y tristeza, cuando la muerte tiende a sofocar «el rumor de la vida», la nostalgia y los recuerdos no dejan de perseguir a don Alfonso. Extraña mucho a su amigo y quiere verlo en Madrid para conversar, beber un buen vino e ir juntos a su amada ciudad de Toledo (este "gran confite heroico») ${ }^{18}$. Y alude también a Burgos, ciudad acerca de la cual publicará (después de un reciente viaje) unas notas en El Universal y años más tarde Horas de Burgos (1932), en Río de Janeiro. De momento se limita a señalar que «de Burgos hay mucho que decir [...] yo escribiré de Burgos, donde fui cartujo unas horas, y casi todas, amapola del campo». En la próxima misiva, del 22 de agosto de 1918, Reyes expresa el temor de que el «soñado viaje» de Torri no se hará. El 30 de agosto vuelve a lamentar su ausencia con motivo de la llegada de Luis G. Urbina, y le recuerda que «la pobreza de aquí es más llevadera y alegre que aquélla». El 15 de octubre Torri acusa recibo de estas dos epístolas y le comunica sus grandes deseos de estar con él, ya que «sólo a tu lado podré ser siempre inteligente y feliz, alegre como una ardilla con su nuez o como un niño con su bonete rojo y su arco» ${ }^{19}$. Por fin, las ansias de don Alfonso culminan en un bello poema en prosa (inédito) fechado el 4 de diciembre de 1918.

A1 recibir la última carta de Torri (15 de octubre), Reyes contesta en seguida, el 24 de diciembre de 1918. En ella se refiere a su reciente «academización» en México ${ }^{20}$ y sobre todo a los preparativos de Nochebuena. Nota una vez más la ausencia de su amigo, aunque reconoce que su carta le proporcionó mucho placer. Fuera de las constantes expresiones de afecto, es interesante destacar la alusión a Ramón Gómez de la Serna, «el pri-

${ }^{17}$ Díez Canedo, por ejemplo, publica una reseña de Ensayos y poemas en El Sol, de Madrid, el 30 de diciembre de 1917. Por otra parte, es de notar que la revista Cervantes reproduce algunos textos del primer libro de Torri en el número de julio de 1917.

${ }_{18}$ Sobre esa ciudad véase En el ventanillo de Toledo, de Reyes (recogido en Las vísperas de España). Es de notar que los dos primeros textos fueron escritos en Toledo en 1917.

${ }^{19}$ Diálogo de los libros, p. 221.

${ }^{20}$ Efectivamente, Reyes ingresa como miembro correspondiente de la Academia Mexicana en septiembre de 1918. Lo será de número en septiembre de 1939. 
mer escritor de España». Reyes señala que él descubrió a ese «bello Ramón» y lo dio a conocer. Le recomienda calurosamente a Torri leer todos sus escritos, los cuales son "de excelente materia y gran ingenio», así como un artículo suyo acerca de ese original narrador ${ }^{21}$.

En cuanto al año de 1919, sólo tenemos dos breves cartas (inéditas) de Alfonso Reyes. La del 13 de febrero - una respuesta a la que le envía su "Julio hermano» el 9 de enero- no es más que una nota apresurada en la cual expresa sobre todo su "gran dolor» al enterarse de que Torri no irá a París como secretario de Alberto J. Pani ${ }^{22}$. A la carta de Torri de octubre de 1919, «llena de promesas», Reyes contesta con unas líneas el 14 de diciembre, en las cuales aprueba sus recientes lecturas (Conrad, Gide) y le pregunta si ha escrito algo para la revista española Poética. Le informa, por otra parte, que ya mandó un nuevo «librito» a «Lectura Selecta», editorial dirigida por el poeta Francisco González Guerrero. Se trata de Retratos reales e imaginarios, que aparecerá en 1920.

Las cartas (todas inéditas) de Alfonso Reyes se hacen más frecuentes en 1920, año en que se reanuda su carrera diplomática gracias a la intervención de José Vasconcelos, de vuelta en México. Antes de este nombramiento, no obstante, Reyes emprende un viaje por diversas ciudades españolas en compañía de amigos como Pedro Henríquez Ureña y Artemio de Valle-Arizpe, quien se encontraba como diplomático en Madrid desde 1919. Torri recibe una tarjeta de Salamanca ( 28 de abril) y otra de Cáceres (3 de mayo), en la cual Reyes califica las ciudades visitadas de esta manera: Salamanca «áurea», Béjar «florida», Plasencia «sonriente», Cáceres «hidalga» y Mérida «blanca». Después de este viaje —según Reyes en carta del 11 de mayo--, don Pedro no permanecerá en España debido al clima y al exceso de trabajo: "Muy rendido, muy triste, vive como en sueños. Es desgarrador." De hecho, en septiembre de 1920 el dominicano ya se marchará de Europa (después de una prolongada estancia) rumbo a Estados Unidos. Por su parte, Reyes se siente verdaderamente feliz con su nueva situación, después de tantas dificultades, como se lo confiesa a su «Querido Julio mío de mi corazón» el 5 de julio de 1920: «Ya supondrás que casi no lo quiero creer. ¿Tener yo seguro el sustento después de seis años de continua lucha e indecisión diaria? (Indecisión sobre si sería o no conveniente comer a medio día y cenar por la noche.) No puedo creerlo, no.» Le causa enorme felicidad, además, pensar que podrá ir con su fami-

${ }^{21}$ Artículo publicado en Hispania (París), julio de 1918, pp. 234-240, y luego recogido en Simpatias y diferencias (1921-1926).

${ }^{22}$ Desde encro de 1919 Pani es enviado extraordinario y ministro plenipotenciario de México en París. 
lia a pasar el verano por el norte de España. De repente, la vida de Reyes toma un rumbo tan distinto que todo le parece un sueño, tal vez el «efecto del hambre atrasada». Sólo le falta la compañía de su querido Julio, cuyas cartas no cesa de saborear: "Yo, personalmente, soy feliz cuando recibo tus letras, y lamento que no te decidas a escribirme más a menudo. A escribirme y a 'escribir'. ¿Por qué no te mandan de compañero mío a esta Legación?» Aunque queda sin noticias directas de Torri, Reyes le vuelve a escribir diez días más tarde ( 15 de julio) con el fin de pedirle textos para el importante semanario España, en el cual él mismo colaboraba con cierta regularidad. Es de notar que España no reproducirá piezas de Torri hasta el 24 de noviembre de 1923, gracias a Juan Ramón Jiménez ${ }^{23}$. En esa misma carta Reyes se refiere a Mediz Bolio, Valle-Arizpe, Icaza y Henríquez Ureña, quien había empezado a comprar libros para el Departamento de Bibliotecas de la Universidad de México, a cargo ahora del propio Torri, siendo rector José Vasconcelos ${ }^{24}$. Por encima de todo, lo que anhela Reyes son noticias de México, de su «protector» José Vasconcelos, de Martín Luis Guzmán, de Antonio Castro Leal y de Genaro Estrada: «Escríbeme largo, cuéntame muchas cosas, muchos hechos exteriores de esos que a ti no te importan y que a mí me hacen falta como a las bestias la alfalfa.» De nuevo el 19 de «julio torri» Reyes se comunica con su "querido mes de Julio» pidiéndole a él y a sus amigos notas sobre la vida cultural de México y textos de Vasconcelos para la prensa madrileña. Pese a la distancia que los separa, es evidente que Reyes desea mantener un contacto íntimo con sus compañeros de generación: «Yo quiero a toda costa colaborar desde acá con vosotros.»

Igual que un par de años antes, don Alfonso aprovecha la Nochebuena de 1920 para comunicarse con Torri (quien le había escrito el 24 de septiembre) agradeciéndole la supresión de las dedicatorias que había puesto en su primer libro de poemas (Huellas), tomo que no publicará Botas hasta 1922. Además, siente que Torri no haya eliminado algunas composiciones, puesto que él ya no puede juzgarlas. Así se lo confiesa: «Quizá hay mucho malo. Yo ya no tengo criterio para ese libro. Debes ayudarme tú. Tal vez ya es tarde. Tal vez ya ha salido al mundo a exponer mi ver-

${ }^{23}$ Se reproducen los textos siguientes: «A Circe», «La vida del campo», «El maestro» y «Caminaba por la calle».

${ }^{24}$ Dice Vasconcelos a Reyes en carta del 7 de junio de 1920: «Me he encargado interinamente de este Departamento Universitario [Rectoría] y me ha ocurrido nombrar a Pedro agente de compras en España. Por conducto de él compraremos todos los libros de las Escuelas, eliminando así el judaísmo de las casas locales.» En Claude Fell, Écrits oubliés. Correspondance entre José Vasconcelos et Alfonso Reyes (México: Institut Français d'Amérique Latine, 1976), p. 36. 
güenza...» Por otra parte, prefiere no ver la nota que supuestamente Torri está preparando sobre Huellas ${ }^{25}$, porque a él le interesa sobremanera la «opinión absolutamente sincera» de su amigo. En el fondo, Reyes se siente muy inseguro, como él mismo lo admite: «En materia de versos soy la desorientación misma. Cada vez veo menos claro, y no me gusta nada, nada, de lo que hacen hoy por hoy nuestros poetas.»

A la larga carta de Torri ( 26 de diciembre de 1920) Reyes le responde con una igualmente extensa e íntima el 30 de enero de 1921 (Diálogo de los libros) acerca de su situación personal (la posibilidad de volver a México con Vasconcelos), de su creciente biblioteca y de su amigo Julio imaginándolo ya casado y a su lado en las legaciones mexicanas de Europa. En esta bella carta Reyes alcanza una rara intimidad al confesar sus temores, sus penas, sus dudas y sus anhelos. Por fin Reyes toma la decisión de permanecer en España, y así Torri es nombrado director del Departamento Editorial de la Secretaría de Educación Pública, puesto que Vasconcelos le había ofrecido a Reyes, como Torri mismo lo señala en carta del 22 de abril de $1921^{26}$. En esa época Pedro Henríquez Ureña regresa a México (el 23 de junio de 1921) para colaborar con Vasconcelos -ahora secretario de Educación Pública- en diversos cargos de suma importancia. Así el grupo ateneísta vuelve a juntarse parcial y momentáneamente, ya que pronto surgirán fuertes fricciones, sobre todo con el dominicano. Es de recordar que gracias a don Pedro se inicia en 1921 la Escuela de Verano para estudiantes extranjeros, en la cual participarán distinguidos intelectuales, como Vasconcelos y Torri, entre otros. En carta dirigida a Reyes el 24 de agosto del mismo año, Torri reconoce que esos nuevos cursos «fueron un completo éxito» y que «vinieron unas norteamericanas encantadoras» ${ }^{27}$. Al año siguiente, en agosto de 1922 , los tres ateneístas salen en misión especial a América del Sur, pero desgraciadamente no tardan en deteriorarse las relaciones con Henríquez Ureña. Después de un largo silencio, Torri vuelve a comunicarse con Reyes y le explica la penosa situación:

${ }^{25}$ En carta de 26 de diciembre de 1920, Torri le confiesa a Reyes: «No he escrito notas bibliográficas para las revistas porque no lo hago bien y además estoy demasiado cerca de lo tuyo.» Diálogo de los libros, pp. 231-232.

${ }^{26}$ Torri le dice a Reyes: «Desgraciadamente, yo estoy abrumado de trabajo: Me dieron el empleo que tú no aceptaste, de Director del Departamento Editorial.» Diálogo de los libros, p. 238.

${ }^{27}$ Diálogo de los libros, p. 239. 
México, IV-9-1923.

Caro Alfonso: No te escribo ha mucho. Pero sólo cosas desagradables tendría que contarte. Por ejemplo, de Pedro me he distanciado completamente. Se ha rodeado de un grupo de muchachos petulantes y ambiguos como Salomón de la Selva, y todo el mundo le llama a su oficina «el taller de fotografía». Avaro, sucio, egoísta, mata-entusiasmos, y lamentablemente viejo de espíritu y cursi de gustos, y de un snobismo ridículo. Vasconcelos mismo apenas lo soporta ya. Te cuento todo esto para que estés enterado de todo. Fue a la Argentina, por ver si allá lo contrataban con más sueldo que aquí; en el viaje de ida fue hablando pestes de México. No va al regreso forzoso. Rompe ésta y escríbeme pronto.

Julio 28

A raíz de estas líneas, don Alfonso reanuda su correspondencia con Torri, la cual había sido interrumpida por un exceso de trabajo en la Legación y por «ciertas novedades [...] de las que no se hablan por carta». La reacción de Reyes a lo que le confía su amigo resulta ser sumamente reveladora, como se puede ver en esta carta inédita del 27 de abril de 1923. Lo que llama la atención, no obstante, es el hecho de que mientras Torri rompe definitivamente con don Pedro, la amistad de Reyes con el dominicano se mantendrá firme hasta la muerte de éste en 1946.

El 6 de julio de 1923 don Alfonso se dirige nuevamente a su «Julio inolvidable» en respuesta a una nota del 15 de junio o «telegrama-epigrama», como lo llama Reyes, quejándose de la brevedad de sus envíos. No solamente le pide más detalles de su vida, sino libros también: «Todos me dicen bien de ti, pero tú no me mandas el original de un libro tuyo, inédito y perfecto para la biblioteca Indice, de Juan Ramón» ${ }^{29}$. Por su parte ya le remitió lo más reciente de su propia cosecha: Fábula de Polifemo y Galatea (Góngora) y la segunda edición de Visión de Anáhuac. $\mathrm{Y}$ espera pronto concluir su gran poema: acaso «acabe de sacar aristas a la piedra dura de mi Ifigenia cruel, entre cuyas piernas paralelas reposamos tú y yo, pobres náufragos del Paraíso».

La última carta madrileña de Reyes a Torri que se ha conservado (también inédita) es del 7 de diciembre de 1923 y responde a una del mes

${ }^{28}$ Ibíd., p. 243.

${ }^{29}$ La Biblioteca de Indice se inaugura en 1923 con la segunda edición de Visión de Anáhuac. Sólo se editaron cinco títulos, como lo indica Reyes en su «Historia documental de mis libros», Universidad de México, IX, núm. 8 (abril de 1955), p. 8. Por lo visto, Torri, víctima de la esterilidad, no pudo formar un libro para esta colección. 
anterior, en la cual su compañero le había complacido con intimidades de su vida. A su vez, don Alfonso se confía a su «queridísimo Julio» y le revela de manera verdaderamente excepcional aspectos de su vida sentimental antes de mencionar, como siempre, sus nuevos libros. También alude don Alfonso a otro tomo de versos que está preparando, «donde hay algo -no dedicado, no: no género: 'A mi amada, para mi querido amigo don Fulano'- sino dirigido a ti, nominalmente». Sin lugar a dudas, se trata aquí del soneto titulado «Años después», recogido más tarde en Obra poética (1952), y que empieza: «Cuando vuelvas a verme, Julio, tarda / en acercarte hasta las confidencias» ${ }^{30}$. Una vez terminadas ciertas obras podrá — como dice Reyes mismo- dedicarse a «los trabajos de mi quinta manera, que viven ya dentro de mí». Por lo visto, Reyes ha tomado en cuenta el valioso consejo de don Pedro, es decir, el de escribir libros de creación en vez de notas periodísticas ${ }^{31}$. Por otra parte, le preocupa la opinión que tienen de él los jóvenes, quienes to han acusado de no ser mexicano, y es por eso que se pregunta: « $\mathrm{O}$ es que hay que fracasar en el extranjero para ser buen mexicano?» Con razón Reyes se indigna ante tal reproche, porque sabe que pese a los años que ha tenido que vivir fuera de México, siempre ha guardado lazos estrechos con su país y sus amigos. En esta carta vuelve a subrayar el gran interés que lo mexicano despierta en él: «Me agrada seguir todo lo de México, pero particularmente aquello en que has puesto los ojos.» La admiración de Reyes por sus compañeros generacionales se revela una vez más en su proyecto (que no se realizó) de formar unos «Cuadernos literarios» con la colaboración de Torri, Henríquez Ureña, Estrada y Vasconcelos. Con el fin de editar un tomo de cien páginas le solicita su ayuda a don Julio: «Me debes de enviar lo más pronto posible $[\ldots]$ lo que tengas $[\ldots]$. No te costará trabajo: reúne todo eso y mándamelo a vuelta de correo.» En este caso - como en tantos otros - Torri ignora la generosa invitación de su compatriota, quien siempre procuraba estimularlo a publicar. Pocos meses después (abril de 1924) Alfonso Reyes se despide de España y hace un viaje a Cuba, México y Estados Unidos antes de establecerse nuevamente en París, donde permanecerá hasta 1927.

${ }^{30}$ Alfonso Reyes, Obras completas, tomo X (México: Fondo de Cultura Económica, 1959), p. 488.

${ }_{31}$ Por ejemplo, el 14 de abril de 1922 Pedro Henríquez Ureña le escribe: «Dice Max que tú pierdes demasiado tiempo; yo también lo creo. Ahora deberías aprovechar el tiempo para escribir cosas tuyas» (Epistolario intimo, III, p. 215). El 5 de diciembre de 1923 vuelve a insistir en la misma idea: «De ahora en adelante no debes ceder a la tentación de hacer notas y comentarios: Escribe sólo cosas tuyas y publícalas, aunque las reciban mal. Acabarán por recibirlas bien» (ibid., p. 254). 
La correspondencia madrileña de Alfonso Reyes con Julio Torri atestigua que los lazos que unen a ambos escritores son realmente muy especiales. De hecho, en estas cartas aparece por encima de todo un Reyes íntimo que se olvida de su propia imagen de hombre de letras. Para él, Torri rebasa los límites de un buen compañero de trabajo para convertirse no solamente en un entrañable amigo, sino en un verdadero hermano. Por lo tanto, este epistolario debe leerse como un auténtico diario íntimo, como un diálogo al desnudo entre dos almas afines. 


\section{CARTAS DE ALFONSO REYES A JULIO TORRI}

Madrid, marzo 1. 1917.

Mi querido Julio: Ya supones el gusto que me daría tu carta del 13 del pdo. dicbre. Para estas fechas, García Monge te habrá enviado mi Visión de Anáhuac. Como hace tan pocos ejemplares, no puedo enviarla a nadie. A él mismo le he pedido que envíe otros ejemplares para Mariano y Antonio Caso. Si puedes, apodérate del que envía a Cultura, y dale mejor empleo. No descuides Cultura. Puede servirte muy bien para relacionarte en América. García Morge te pedirá algo para el Convivio. ¿He de recomendarte que aceptes? Falta de tiempo, no de voluntad, me han impedido enviarte una colección de artículos para Cultura. En mi Visión, etc., además de la errata que el editor señala, corrige, pág. 26 , línea 3, donde dice: pegadas $a$, y debe decir pegadas $y$. Chucho se ha marchado para El Paso, y aún no me escribe. Creo que ya no se acuerda de mí. Pablito está completamente entregado a la vida aristocrática de Madrid, donde entre los títulos sus parientes ha encontrado su verdadero medio. Para que no se le acuse de ligereza, lee todos los días un poco de griego. Pero en el fondo le importa muy poco nuestra vida, y yo no puedo ser pleno con él. Siempre exquisito y amable, con una cortesía llena de deliciosas torpezas infantiles. No me acompaña, ni tengo tiempo. Eres tú quien debía estar por acá, y todas las noches te sueño. Gracias por lo que me cuentas de tu vida. A Mariano le he escrito una absurda carta que lo va a poner de mal humor. No me hagáis caso. ¿Quieres dar las gracias a Toussaint por su Sor Juana, en tanto que yo le escribo? Muy fino tu Andersen. Venga, pues, tu libro. Tú mismo ven. ¿Qué diablos haces allá? Saluda a Lolita. Tu hermano,

General Pardiñas 32.

Alfonso 
Madrid, 20 de septiembre de 1917.

D. Julio Torri.

En México la ciudad.

Oh mi querido Julio, mi leal verdadero:

Me muero de gusto cuando recibo una carta tuya. La última, relativa a mis Cartones de Madrid, me llega dos días después de la partida de Pedro, y me consuela un poco. He quedado sumamente complacido, y muy agradecido de ti y de Toussaint, a quien lo dirás así en mi nombre, te lo ruego. La portada del tomito es un verdadero acierto, y algunos amigos exigentes de aquí a quienes lo he mostrado, opinan lo mismo. La lista de erratas que te enviaré en otra no tiene por objeto censurarte, sino «depurar el texto». Ya estoy demasiado corrido para disgustarme con las erratas, ya no tengo esa histeria de los escritores primerizos; ya sé, sobre todo, que todo el esfuerzo humano es inútil. La errata es un microbio, no se la puede destruir ni a la temperatura del plomo derretido de la linotipia. De manera que tú, queda satisfecho y tranquilo, que más que yo lo estoy no podrás. Te agradezco la pena de hacer los paquetes y enviarlos, enojo sólo comparable al de parir (me imagino yo). Pero he de darte un consejo: haz tus paquetes siempre pequeños; comienza por envolverlo todo en un papel, que ni sea tan desgarrable como el de periódico ni esté acartonado y quebradizo; después, envuelve todo eso en un cartón flexible, rudo, especial para envolver, que se vende por ahí en las «Fábricas» de cartón, procurando que dicho cartón cubra las cuatro caras de tu paquete (¿estamos?); después, pégale en la cara que te parezca más digna e importante un papel de escribir con la dirección, etc.; finalmente, átalo todo (o ata el todo) con una cuerda en cruz, muy fuertemente, haciendo unos nudos terribles, más que ciegos, pero cuidando de disimularlos con una graciosa rosita que haga creer en el correo que el paquete es fácil de desatar. A todas estas reglas añadirás la mejor, que es darlo a hacer siempre a alguna persona manual, a algún hombre de dedicaciones más mecánicas que las tuyas. Todo esto viene a propósito de que tus cajas de cartón llegaron medianamente deshechas. Mi correo tuvo a bien sustraerlas de la aduana, pero quién sabe por dónde se escurrieron siete ejemplares que me faltan, sobre los 75 que habían de ser. Ya te diré si los cobro. Gracias por el artículo de Arkel, Carlitos. Dale las gracias en mi nombre, y dile que conservo con todo afecto su recuerdo. ¿Con que me llama «raro»? Recibí también otro artículo sobre los Cartones, de cierto Lic. Vidriera, al que no menos le

¡Por los dioses: no me llaméis licenciado, sino doctor, en vuestras cartas! 
agradezco. Sois mis verdaderos hermanos; cada vez que me siento en contacto con vosotros, repito, quisiera morirme de gusto. En efecto, mi librito está muy atractivo; me ha gustado mucho ahora que lo he repasado. ¿Crees tú que puedo morir contento?

Nuestro Pedro estuvo aquí dos meses, que parecieron dos días, y aun menos. Nuestro Pedro fue aquí recibido con una voluntad más eficaz y franca que como se le recibió en nuestra tierra, allá de recién llegado. Bien es cierto que aquél era casi un niño, y el que vino a Madrid es ya un señor de fama hispánica, que realiza casi el pequeño ideal de Chocano: tener el Continente a sus pies. Yo le regué la senda de flores, yo le preparé el terreno y le abrí todos los corazones. Aquí son muy buenos, Julio mío, muy buenos. Pero el ambiente tiene algo de crueldad y escasez. iOh, quién hiciera un ramillete con las cualidades mejores de los pueblos! ¡La: gracia y la armonía de París, la bondad y la genialidad de Madrid, la sensibilidad profunda y la trascendencia psicológica de México! Ese habría resuelto el verdadero problema político, que consiste todo en hacer del pueblo un dechado de las virtudes, y una suma (no una resultante caprichosa e incierta) de las cualidades de sus individuos.

Pero vuelvo a Pedro. El pobre venía a descansar; pero hubo de trabajar; algunas notas nos dejó para la Revista de Filología Española (a la que conviene acostumbrarse a designar con la sigla RFE, para abreviar), y, desde luego, casi hizo sólo una antología de poetas americanos que pronto daremos a Calleja, y que lleva los nombres de él, de Enrique Díez-Canedo (EDC) y mío. Muchos proyectos dejamos planteados, y cómo -una vez habiéndonos vuelto a encontrarnos nos sentimos ya más fácilmente comunicables - los iremos realizando, sin empacho de que él viva en Minnesota (llamémosla «Mesopotamia húngara») y yo aquí. Yo descubrí con gran placer que había evolucionado paralelamente a él en las cosas fundamentales. El creo que me encontró digno de mayor confianza que antes, si cabe. Los dos estamos encantados, y robustecidos para luchar solos por un año más. Hablamos mucho de ti, a todas horas; te abrazábamos entre los dos, te sentábamos a nuestro lado y te dirigíamos la palabra: una noche tuve una seria discusión contigo, sobre si la esgrima del florete a la italiana era o no superior a la francesa. Pedro pasó dejando una onda de simpatía tras sí, y alguna inquietud espiritual de esas que él sabe suscitar siempre. ¡Atense los vientos del mar, júntense las aguas al curso del barco que se lo lleva!

Sí: Pablito se me va también. El mes entrante se embarcará, y como está de veraneo en Zarauz, no le veré más. ¡Ay de mí! Si tú puedes allá, hazlo que resucite La Nave. Yo vivo tan ocupado, que apenas-apenas disfruté de él, y me quedo con el duelo de haber desperdiciado un poco sut 
estancia en Madrid. Ya él te dirá: ha estado luchando constantemente entre el amor y el desamor a esta tierra. Así vivimos en el extranjero todos los hombres. Los de allá particularmente, echamos de menos la dulzura de aquel trato, que enamora y enhechiza a los que lo han conocido. Ciudad como aquélla en esperanzas y en promesas ¿dónde la habrá? Porque en recuerdos gratos, claro es que para mí no puede haber otra. Te diré, tampoco me olvido de mis malos recuerdos. Pero ¿qué tienen las ciudades que siempre se hacen perdonar? ¿Qué cosa es esa alma multánime, que vuela sobre las casas de los hombres? Yo pasé unos cuantos días infernales en Burdeos, y mira tú: la recuerdo con lágrimas de amor. Ya te explicaré todo eso en una carta muy larga - tan larga que se ha convertido en libro- que te estoy escribiendo en mis ratos de ocio, y que aún no sé si publicar aquí o enviarte a que la publiques allá. Se llama: La estrella del sur, y es la historia de mi declinación hacia el mediodía, mi viaje espiritual desde París a Madrid. Hará época en la historia de nuestra amistad. Only this and nothing more.

No: Pedro no tiene para qué 1levarme a Minnesota. No estamos seguros de que sea preferible eso. Mi destino está más aquí que allá. Sus opiniones de aquel pueblo no son las de la infancia que conocimos; te diré: ahora se parecen más a las de todos los hombres. ¿Lo ves tú? Los hombres no se engañan tanto como pretendemos los artistas de cualquier arte. Me parece que allá en las intimidades de su corazón, Pedro ha dejado crecer la yerba de la melancolía, pero en general se conduce con más desenvoltura que nunca; se halla mejor en todas partes, y nunca se olvida de que el espíritu es la fuente de la felicidad. Yo creo que está un poco fatigado, y aun temo que expuesto al surmenaje. Figúrate que ha cogido la costumbre de hacer siempre dos cosas a un tiempo, y no hay manera de quitársela: así, mientras se afeita, escribe sus cartas (a veces escribe con la navaja y se afeita con la pluma); mientras deletrea un trozo alemán de Hebbel, escribe un artículo sobre las influencias de Pedro Espinosa en la poesía romántica. Trabaja siempre con la nota más aguda, y eso suele fatigar el instrumento; pero yo no he logrado acostumbrarlo a descansar. Hay que tener horas de estupidez, de paciente animalidad, de insensibilidad pétrea; pero él es todo lumbre y estrella vigilante, todo centelleo y vuelo de altura.

Espero con sed tus Ensayos y poemas, y agradezco a Genaro Estrada el obligarte a publicarlos. Abandona todo pudor. No nos pertenecemos: todas nuestras palabras debemos ofrecerlas a los hombres. $Y$ yo te aseguro que alguien, a través del tiempo, las espera para vivir por ellas. Tengamos la fe en los hijos del espíritu: la voz que nos ha de responder nos está esperando. Yo no podría vivir sin esta fe mística, profunda, en las conso- 
nancias de los espíritus. Tenemos la obligación de continuar, para los que nos sigan, el «iCentinela, Alerta!» que alguien ha lanzado en los comienzos de las cosas...

Están muy bien todos los nombres que me indicas para enviar tu libro. Puedes enviarme a mí todos los de Madrid; a mí me gustan esas distribuciones, sobre todo tratándose de cosa tuya. Además, son excelentes ocasiones de distraerme un poco de mis afanes, de cambiar ideas, ver las caras de los amigos, y entregarme en fin a la más perfecta de las danzas: la danza del trato humano. iY pensar que algunos creen que la virtud es la soledad! Puedes añadir a tu lista a Juan Ramón Jiménez, Francisco A. de Icaza (no olvides a nuestro pobre Icaza: ya te contaré), al Ateneo. Ya te indicaré otros después, cuando lo reciba. Los demás que ahora recuerdo vienen en segundo lugar. Pero, desde luego, envíame algunos en blanco, para algún objeto de propaganda. Sí: Nervo sigue en la Legación; pero también puedes enviármelo a mí. En París, no olvides a los hermanos Calderón, a R. Foulché-Delbosc (aunque te parezca extraño: hace caso y se interesa por nosotros; es muy buen amigo mío, aunque no de sus enemigos).

Quisiera pedirte un favor muy especial: que no dejes de acusarme recibo en una tarjeta postal cuando te envíe algo mío; porque puede olvidárseme si te he enviado o no alguna cosa. No sé si te envié mi primer artículo (en «separata» de la RFE) sobre el monólogo de Segismundo. Dímelo, porque pronto saldrá el segundo (lo acabo entre hoy y mañana: es más importante que el primero), y quiero enviártelo también. A Genaro Estrada estamos obligados a darle todos los datos sobre nuestra labor. Es el organizador de nuestra historia literaria. Yo le envié una lista en una carta. Pronto le enviaré datos sobre artículos publicados en la Revue Hispanique, en el Boletin de la Academia y en la RFE. Dime si recibes mi edición del Arcipreste de Hita. El mes entrante publicaré, también en Calleja, unas Páginas escogidas de Quevedo que te enviaré. A los amigos en general, pídeles perdón por mí: no dispongo de ejemplares, no siempre puedo enviarlos. Y ¿cómo no voy a preferir a mi compañero de banco de escuela? Es un poco una preferencia de orden doméstica, por la que no tiene que ofenderse nadie. A mi querido Mariano no lo echo en olvido, y él recibirá mis recuerdos conforme se vaya pudiendo. Quiero que me digas (no se te pase) si se recibió en México mi «Visión de Anáhuac» publicada por García Monge (no Monje) en el Convivio, Costa Rica. Nadie me ha hablado de ella de México. Quizá hasta la podríais reimprimir en Cultura, aunque ignoro si esto cabe en vuestros planes. Si así fuere, dímelo para que te envíe nota de las erratas del folletito. $\mathrm{Y}$ te daré una regla, porque presiento que las cartas de encargos no te hacen feliz: cuanto antes despá- 
chalos; cuanto antes haz lo que en este párrafo te pido, y verás así qué cómodo es. Y gracias. Y nada más.

¿Mi hijo? Cabezón, chato, moreno (un tiempo fue rubio), con las rodillas descalabradas, como todo niño robusto, de salud normal, sabe andar descalzo (como cualquier digno ciudadano de la tierra), el cuello algo delgado para mi gusto, travieso sin llegar a enojoso, nervioso como era inevitable (joh tiempos!), algo golfillo y capaz de hacerse valer solo, lo que me contenta; lo dejo ser un poco grosero con las gentes y los otros niños, por experiencia propia; nunca leerá el «Corazón» de Amicis ni cosas por ese estilo. Conoce algunas letras, y pronto comenzará a ir al kindergarden. Se deja arreglar una muela como si fuera persona mayor, y sin darse cuenta de que el dentista es un coco. Me quiere mucho, sin acariciarme demasiado. Anda todo el día en la calle, frente a mis ventanas. No tiene acento propio al hablar, porque habla siempre con el tono de voz del último niño con quien ha jugado; pero eso sí, sus modos de hablar muy propios y originales: por raro atavismo inexplicable, usa formas de Monterrey («el riyo», etc.), mezcladas con términos madrileños («ihay que ver!», «Di que sí», etc.). A todo el mundo le corrige su manera de hablar, porque lleva desesperantes trazas de académico de la lengua: «No se dice así, sino asao». En fin, es un buen animalillo, y ya con eso me conformo por ahora. De su profesor de baile, Il Torri, tiene algunas vagas nociones.

Mi mujer corresponde a tus saludos. Yo creo que la guerra no acabará en este año, ¿no es verdad? Y quedo, como siempre, esperando tus cartas que tanto bien me hacen (Dime: El suicida no ha gustado allá, ¿verdad?) Tuyo,

General Pardiñas 32.

Alfonso

(ipluma berraca!)

22 Septbre 1917.

Querido Julio: Bien pocas erratas, ¿verdad? Ya ves que estoy satisfecho. Gracias por todo. ¿Queréis enviar un ejemplar a mi madre? $\left(5 .{ }^{a} \mathrm{Ci}-\right.$ prés 160 , Sra. A. O. de Reyes).

Espero con ansia tu libro. ¡Si te habrás arrepentido después de impreso! No te escribo más por hoy. Mañana domingo me voy a la sierra de Guadarrama, a comer con Menéndez Pidal en su casa de campo. En estos momentos recibo de Vigo una carta de Pedro, próximo a embarcarse: me habla del paisaje húmedo y con pasto de Galicia, opuesto a la roca seca y morada de Castilla.

Tuyo,

Alfonso 
Erratas y correcciones

$\begin{array}{rlc}\text { Pág. } 24 & \text { lín. } 20 & \text { dice: paletós } \\ \text { Pág. } 25 & \text { lín. } 13 & \text { dice: ¡He } \\ \text { Pág. } 48 & - \text { última } & \text { dice: objetos } \\ \text { Pág. } 51 & -1.9 & \text { : le } \\ 52 & -3 & \text { que } \\ 57 & -29 & \text { desgarrado } \\ 62 & -6 & \text { iOn } \\ 72 & -1 & \text { por }\end{array}$

Pág. 76 línea 3. ${ }^{\mathrm{a}}$ de abajo arriba.

$\begin{array}{ll}77 & \text { verso } 2 .^{\circ} \\ \text { íd. } & 1.3 .^{a} \text { de abajo arriba } \\ \text { id. } & 1.2 .^{\mathrm{a}} \text { " " } ~ \\ 88 & 24 \\ 95 & 6\end{array}$

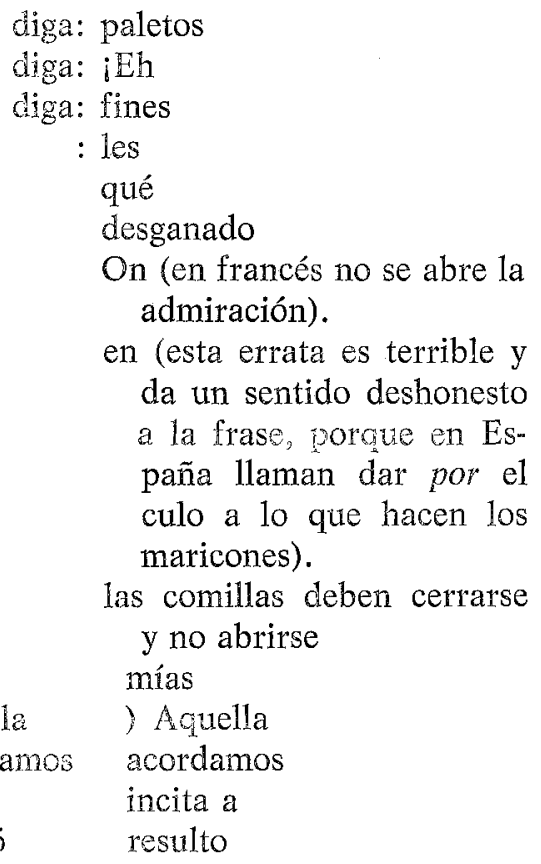
admiración).

en (esta errata es terrible y da un sentido deshonesto a la frase, porcue en España llaman dar por el culo a lo que hacen los maricones).

las comillas deben cerrarse y no abrirse mías ) Aquella acordamos incita a resulto

Madrid, 7 de enero de 1918.

Mi carísimo Julio: Cerrada ya esta carta, el correo me trajo la tuya de un claro día de noviembre (oh cielo de México). Tu carta llena de íntimo calor, en que me anuncias la llegada de nuestro fino Pablito (fino como una daga de oro). Ojalá que os acompañéis con toda la apacibilidad que os deseo. Yo, ya te lo he dicho, no gocé todo lo que hubiera querido de su compañía: icon decirte que ni de la de Pedro! Y esto por esa provisionalidad, por esa crisis de mi vida de que apenas espero salir este año. Pablo ha hecho intensa vida social en Madrid: por eso lo encuentro más humano. Te hablará de su amigo Alvaro Alcalá Galiano: tengo el deber de manifestarte que su inteligencia (revelada en sus obras vale muchas veces menos que su amistad, de la que Pablo es un inapelable testimonio. He recibido también carta de Pedro, cuyo contenido esencial te comunico, porque es orientador: vuelto a los Estados Unidos, Pedro ha comparado, 
y decide que para él, para nosotros, Madrid es mejor y aun permite una vida civilizada y literaria más intensa y real. Acaso allá hay que ser siempre un espectador un tanto humilloso.

Tu carta me descubre algunos rincones íntimos de tu vida: y contigo, mi querido Julio, lo más pudoroso de ti mismo, son tus cosas íntimas (no es tan frecuente el caso como parece). De modo que lo que más estimo y de tus cartas son esas confesiones. ¿Congreso de comerciantes? ¿Cómo es eso? ¿Acaso es una «chamba» aparte de tu trabajo oficial? Tú ¿qué eres actualmente? ¿Cuántas cosas haces? Yo espero que ya habrás hablado con Luis Urbina de ciertos proyectos: joh, si se realizaran! ¡Oh, si tus nuevos deberes te permitiesen! Oh, Julio (Decididamente, yo no sé hablar contigo más que en interjecciones: ¡Oh, ah!, etc.).

Casi... bien: casi eso que tú me dices. No quiero repetirlo. Crei que eras algo más feliz. Todos nosotros somos hijos de la conversación es verdad.

Debo acabar. ¿Qué más da que cierre este pliego, puesto que muy pronto te volveré a escribir? Sed felices, tú y los tuyos. Hoy llueve tristemente sobre Madrid; pero no llora en mi corazón. Ya te enviaré mis versos. Son buena compañía, te lo aseguro: tú sabrás descubrir en ellos todo lo que hay en los espacios blancos donde la máquina no ha clavado su tipo.

He recibido juntas cartas de ti, de Pedro, de Chacón. Sólo de París, los García Calderón se me van volviendo un poco ingratos, por culpa de Fombona. Ya te contaré este chisme algún día. Ventura no ha sido inteligente. ¿Sabes algo del injusto Acevedo?

Tuyo

General Pardiñas 32.

Alfonso

¿Y Caso, mi querido Caso?

En cada una de tus cartas ponme tu dirección, te lo ruego.

Mury querido Julio:

Madrid, 3 de mayo 1918.

Fitzmaurice-Kelly me escribe manifestándome deseo de conocer los trabajos de Rangel sobre Ruiz de Alarcón. Te ruego que le pidas a éste un ejemplar de todos los números del Boletín de la Bibla , en que se publi- 
caron estos trabajos, y les ponga una palabra de dedicatoria, para enviarlos yo a mi amigo.

Un abrazo

General Pardiñas 32.

Alfonso

Madrid, mayo 5 de 1918.

Querido Julio: Le enviasteis un ejemplar de «Mimos» a Solalinde, excelente amigo pero no literato. ¿Le podríais enviar uno a José Moreno Villa, que lo desea? No lo olvidéis en adelante en vuestras distribuciones. Su libro «Evoluciones» es excelente. Te lo enviará. Le he dado ya tu libro «Ensayos y Poemas». A fin de este año publicaré «El Cazador», recopilación de artículos desde hace siete u ocho años, que me dejará las manos libres para las nuevas cosas. Estoy en la dura tarea de copiar versos que ya me quedan muty lejos, para enviártelos.

Un abrazo, y saludos a los amigos.

General Pardiñas 32.

Alfonso

28 de julio 1918. Madrid.

Caro Julio:

Te escribí de Burgos la ciudad una tarjeta consoladora, por la inquietud de tu última carta, de 13 de mayo. No sé qué necedades te habré dicho. No hagas caso de lo que digo: sólo de lo que pienso. Eso tú lo sabes muy bien.

De manera que todavía el 13 de mayo no sabías si al fin vendrías a Madrid. iY yo que te creía casi de viaje y me resistía a contestarte, por si no te llegaba a tiempo mi carta!

Pedro está en California: veremos si de allá viene a Madrid. Chacón está en Madrid. García Monge sueña en venir. Venid, oh, venid.

Al Marqués no le escribo: creo que él me lo perdonará. Para enviarle saludos y para decirle que ya está el original de su libro en mis manos, según sus deseos, casi es más elegante confiarte a ti mi representación, y que tú lo hagas en mi nombre.

Tus últimas cartas son las mejores que me has escrito en tu vida, porque al fin me has escrito todo lo que tenías adentro, aunque después ha- 
yas pasado una simbólica raya de tinta sobre lo que te pareció excesivo. Naturalmente, yo lo leí todo, aun lo tachado. Y te quedo muy agradecido.

Me imagino que Luis Urbina vendrá por septiembre $\mathbf{u}$ octubre, que es cuando se entra a Madrid. En el verano sólo yo vivo aquí, y me escapo todos los días y horas que puedo. Y si Urbina viene con el otoño, con el otoño pudiera venir Julio, como una súbita flor de prinavera. Juan Ramón me dice que le has escrito: ya estaba algo inquieto por no saber de ti, me alegro que lo hayas hecho. Aquí los que valen te conocen, por ti y por mí: más por ti que por mí. Y te aman, menos que yo, porque en eso ¿quién me igualaría?

Yo soy una gran tristeza alegre, algo dorada y roja, visos morados y verdes, y música de agua y de timbre eléctrico. ¿Te gusto así? Pero todavía conservo algunas virtudes de papel de estraza, y el otro día tuve en Burgos un franco éxito tirando el rifle en la feria, en la plaza de la fuente de la Flora. ¿Te acuerdas? Pues allí, allí mismo fue: sobre el muro del fondo, saltan las últimas agujas de la Catedral: nuestra Catedral, Julio, diminuta por lo que la amamos, y que queremos guardarla en un escriño, como dicen de Felipe II (¡Este Felipe II de mis pecados!).

A otra cosa: yo soy una gran alegría triste, ceniza. No sé si el baño de regadera (que aquí llaman de ducha: no saben aquí lo que son duchas) me sienta bien o mal por las mañanas. A veces creo que me pone los nervos tirantes, como cuando los violines quieren gemir solos, sin el roce del arco. Y claro está: a veces tengo que irme de allí a ordenar papeletas en el Centro de Estudios (donde se te espera para clasificarte en cruz, o en «zuástegui», ¿no me entiendes?), porque todos -no sólo tú- solemos barrer la calle a ciertas horas.

Pero tú, Julio, ¿en qué piensas? ¿Es verdad que mis cartas te hacen tanto bien como a mí las tuyas? ¿Te acuerdas una noche en que trí te adelantaste, y cuando todos llegamos ya te habías vestido de mujer? ¿No te acuerdas? ¿Eres como todos? ¿Ya no te acuerdas?

$\mathrm{Me}$ dicen que vas a escribir novelas. Yo estoy escribiendo una: La casa del grillo; pero tal vez acabaré antes otrá que se llama «A moquete limpio» (¿Me habré vuelto loco, Dios mío?).

¿Quieres darle a nuestro amigo Rafael Cabrera la carta adjunta? Es el tamaño oficial de las papeletas del Centro de Est. Históricos. Es la unidad científica. Respétala y no la uses: todos los antiguos empleados de esa casa enloquecen primero, y después se mueren. En España da mucho gusto ir a un entierro. Cada vez las paladas de tierra suenan más fuertes, se apoderan de nosotros, y nos dejan escuchar y oír menos el rumor de la vida. 
Julio: yo te espero en Madrid. Julio: ven. Nos va a dar mucha risa encontrarnos algo envejecidos, y yo te ofrezco que beberemos juntos un buen vino dorado. En Toledo tengo una casa, tenemos más bien: Castro, Moreno Villa, Solalinde y yo. Toledo es un gran confite heroico. Pelearía uno hasta morir por Toledo: se comería uno a Toledo una noche de gula canonical. Si tú lees «El Gráfico» de Martín (¿y quién que es no es romántico?), acaso te encontrarás unos versos míos: allí Toledo.

Pero de Burgos hay mucho que decir. No sé si mis notas estarán bien tomadas. Porque la presencia de una sensibilidad demasiado alerta según la manera usual, y exprofeso movilizada para en caso de disparo estético -que me acompañaba: nunca bastante tornasol a mi paladar-, y aún aún. ¿Has entendido? En todo caso yo escribiré de Burgos, donde fui cartujo unas horas y, casi todas, amapola del campo.

$Y$, Julio, como quiera que sea, ven a Madrid. Y cada vez que me escribas dime el estado práctico de tu vida: cuéntame si adelantan esos arreglos, cómo vas de esperanzas, qué hay de promesas, y cuánto de despecho.

Otra vez, otra vez tengo un gato en casa. Si tú fueras tan mi amigo como te precias, al menos me contarías qué fue de mi Juan Alvarez Gato, gata en quien fundé esperanzas y conseguí dulzuras. ¿Sabes de ella? ¿Ascendió a la Luna, en los remolinos de la noche del tiempo? ¿No la dejó Pedro a tus cuidados? ¿Os la dividisteis - hermanos al gusto del poema del «Vértigo»- como os dividisteis (feos) sus libros? (Los de Pedro).

Mi nuevo gato se llama - así lo llamó el plebeyo que me lo dio, que no fui yo, que no fui yo- se llama «Pepe Bufa», y casi habla. Grita para charlar conmigo. En este instante acabo de arrojarlo de aquí, porque cayó sobre mi archivo de cartas, metió las garras en la T y sacó, precisamente, dos cartas tuyas.

Mi hijo es un morenito de color verde. Crece como espiga en abril. Manuela te saluda y dice: que cuando vengas, ya te echaremos de comer. Y yo, que sí y que sí.

Esto Julio te digo, y si vacilas, acuérdate que tienes dos pupilas

a quienes educar.

(Los ojos no se educan sino mirando el mar.)

Adiós, escribe pronto, y aunque se te entienda. $Y$ ven, ven, ven.

General Pardiñas 32.

Alfonso 
Madrid, 22 de agosto de 1918.

Mi querido Julio: Sin nuevas de ti, me temo que el soñado viaje a Madrid no se realice. Envidio los poderes de Chacón, que está conmoviendo a La Habana para hacer que Lizaso venga a su lado. Probablemente Urbina aplaza sus proyectos hasta el Otoño, y hace bien, porque pasamos un calor espantoso. En estos días me he vacunado, con toda mi tribu. A mí me ha prendido de una manera atroz. $Y$ el sol y el calor me han provocado -física y moralmente - lo que el vulgo llama un «hervor de sangre».

Esta carta tiene un fin oficial: cumplir un encargo de Juan Ramón Jiménez, que tú comunicarás a los amigos interesados. Juan Ramón ha visto con pena, en el Tricolor de julio, una entrevista de Julio Sesto que a mí más bien me parece anodina, pero que a él, que es delicadísimo, le ha irritado. Las frases dedicadas a la doncella de Juan Ramón indican lo que es Julio Sesto. Juan Ramón lo recibió un día y le dijo dos o tres cosas corteses y nada más. No admitió, ni se trató nunca, de escribir para Tricolor: el que pueda creerlo no conoce a Juan Ramón. Es éste un hombre cuyos únicos defectos, que lo hacen intratable para algunos, proceden de su mayor cualidad: quiere que todo sea puro y perfecto. Lo único que hizo Juan Ramón fue, como persona bien educada, darle unos libros a su visitante, para que reprodujera lo que él quisiera. No es verdad que se hayan abrazado. Tampoco es verdad (y es lo que más le lastimó a Juan Ramón lo que Julio Sesto dice sobre su colaboración para Cultura: le dijo simplemente lo que hay: que Pedro iba a escribir el prólogo para su antología de versos de Cultura. Si Juan Ramón necesita consultar algo sobre México, me tiene aquí a mí. ¿Lo ignora ese mentecato de Julio Sesto? Pero, por lo demás, para cuando Uds. invitaron a Juan Ramón ya éste sabía muy bien, por mí, lo que es Cultura y quién eres tú, cuyo libro aprecia en lo muchísimo que vale. ¿Por qué consentís a ese imbécil que nos falte a todos al respeto? ¿No podéis expulsarlo? A mí me lo quiso traer Frías, y yo no lo consentí. No es verdad que haya dicho nada, nada de todo eso que le atribuye Sesto.

Hasta otra. Tuyo

De todo esto no tiene él la culpa. 
Caro Julio:

Madrid, 30 Agosto 1918

Llega Luis el diplomático y no te trajo consigo: otro [...] se me desvanece. ¡A quien él persiste en querer traer es a Rangel! De ti sólo me dijo que le parecías triste. Sé que ya no hay dirección de Bellas Artes. Julio: cuando seriamente pienses en venirte, agénciate el viaje, y avísamelo. Donde yo llevo cuatro años de vida, ya puedo abrirle paso a un amigo. La pobreza de aquí es más llevadera y alegre que aquélla. No lo olvides.

Tuyo

¡Oh, Julio, Julio!

Alfonso

Madrid, 4 dic. 1918.

Julio, hermano mío: ¿dónde estás? En la Navidad te habrás acordado de mí, y habrás oído mi bastón por la calle, y en la oscuridad de la noche, creerás ver la chispa roja de mi cigarro. Héme, alumbrando con los ojos la senda por ver si te hallo. Ya estás aquí, al otro lado de esta mesa redonda, los pies junto al brasero andaluz. A veces miras sin ver desde una cara blanca, blanca (¿por qué tan lívido, Julio mío?). Pero otras veces tiemblas todo y dices - con una voz que conservo adentro- «iCaramba! ¡Caramba!»

¡Caramba, hombre, con cien mil de a caballo, ven a España!

Alfonso

Te buscará en mi nombre un joven paisano: Alfonso Junco.

General Pardiñas 32.-Feliz año.

Madrid, 24 de diciembre de 1918 (Noche Buena).

Y casi ya encima la noche, Julio mío, recibo tu carta del 15 de octubre, con el recorte en que consta mi flamante academización. Tenía noticia de todo por Urbina, a quien se lo comunicó Juan B. Delgado. Yo le escribí a Delgado pidiéndole que manifestara mi gratitud a todos, y en especial a Don Pepe López Portillo, reservándome el escribirle directamente a Enrique Gonz. Martínez, seguro de que por él me venía la cosa. 
Así lo haré mañana mismo. Entre tanto, fuerza es que sepas que tu carta me ha venido alegrar esta Noche Buena, y se me confunde con la Sidra, el curazao, los fiambres, el capón, el pavo, el turrón y el mazapán, y mil otras cosas que acabo de traer a casa para la cena de Noche Buena. Además de la Santa Trinidad, cenarán aquí la madre de Solalinde y una hermana suya (viven a dos pasos, y él, muy pillo, como buen hijo de familia, prefirió escaparse y pasar la Noche de Dios en Toledo, en una casita que tenemos, Callejón del Vicario, 13, que se llama El Ventanillo, de que somos copropietarios, o coinquilinos, Solalinde, Américo Castro, Moreno Villa y yo). También bajarán de otro piso de esta misma casa en que moran unas señoras mexicanas que se han quedado muy pobres después de disfrutar de una renta mediana que les dejó el marido (de una, y de la otra padre), que era un español de Veracruz. $Y$ no sé si lograré disiparle la neurastenia a José María Chacón, que vive en el segundo piso de esta misma casa. Esta mañana fuimos juntos al Rastro, y de pronto, porque empezó a llover, dijo que se iba a morir y que estaba muy enfermo, por lo cual no podría bajar esta noche. Veremos. Inútil decir que me faltas tú: al menos no tu carta. Me divierten las noticias que me das. Pobre maestro Revilla, lo reconozco. No me hablas más que de el Alarcón de La lectura. ¿No has recibido otro más popular, de Calleja, así como el Gracián y el Quevedo de Calleja? Me tranquiliza saber que estás rico: sufría por ti. Cuando te sobre algún dinero, mándame con él alguna cosa de nuestra tierra, aunque sea un sombrero charro: yo me lo pondré para ir al Café de Pombo las noches de banquete, a hacerle los honores a Ramón, el primer escritor de España. (No hablo de Valle Inclán, ni de Menéndez Pidal, ni siquiera de Pérez de Ayala, sino de otro nuevo y bello Ramón que yo he ayudado a poner en el lugar que se merece, y a quien antes de mi era no le hacían caso aquí, sin duda por cobardía mental y por pereza: Gómez de la Serna. Te enviaré cosas de él: deshilvanadas, pero de excelente materia prima y gran ingenio. Lee de él cuanto encuentres. Y, si llega allá la revista Hispania, no la de California, de los maestritos yanquis de español - que por lo demás es útil-, ni la que antes se publicaba en Londres, sino la reciente de París, Ecole de Hautes Etudes Hispaniques, bajo el cetro de Ventura García Calderón, allí encontrarás un artículo mío en francés sobre el dicho Ramón, que me ahorra todo comentario. Te escribo de un modo absurdo, a fuerza de abundancia. Lo mejor será que se remansen las aguas. Ya seguiré mañana, si me deja con humor la cena de esta noche. Julio mío: te espero siempre. No lo olvides, y sepa el mundo que muero invocándote. Ya no me acuerdo si he abierto un paréntesis o si lo he cerrado. Por las dudas: ().

Día 25: Hoy me llega carta de Genaro Estrada, fecha 6 de noviembre. 
Y una de mi madre. Por lo visto estáis todos con gripe. Aquí la hemos pasado ya casi todos. Os enviaré cosas informativas para La Nave, cuya vida deseo muy larga. Martín me escribió en efecto, que había estado en México y os había visto, pero es hombre que no sabe dar cuenta de las cosas: todo se lo guarda. Sólo me dice que se va a hacer muy rico y que ya no quiere ser literato. Va a jugar a otro juego. De Vasconcelos tengo reflejas noticias por Pedro. Este ha sufrido horribles operaciones en garganta y nariz, y amores de cursis ya yancas de California: todo buena cosecha, como diría el querido monstruo leonés. No estaría por demás que me hicieras un favor muy grande: completarme la colección de «Cultura». Me faltan:

1,2: Rodó, con pról. de Pedro.

I,3: Cuentos de Gutiérrez Nájera.

II,1: Darío, Versos selectos.

11,2: Prosa, de Altamirano.

II,4: Poemas de Othón, monos de Ruelas.

II,5: Escritos de Varón, prólogo de Caso.

II,6: Poemas de Valencia, prólogo Toussaint.

III,2: Poesías selectas de Rueda.

III,3: Guillermo Prieto, prosa y verso.

III,5: Prosa de Justo Sierra.

III,6: La V. Ursula de D'Annunzio.

IV,2: Teatro de Alarcón.

IV,4: Escritos etc. musicales de Ponce, prólogo de Campos.

IV,5: Hermann y Dorotea, de Goethe.

V.1: Herrera Reissig, Extasis de la Montaña.

V,3: Antonio y Manuel Machado.

VI,6: El Pensador Mexicano, diálogos de su tiempo.

VII,1: Rémy de Gourmont.

VII,3: Heine, Noches Florentinas.

VII,5: Cuentos de Anatole France.

VIII,1: Prometeo encadenado Esqutilo.

VIII,4: Selma Lagerlof.

VIII,6: Omar-Khkjltfhdgryama.

Y todo lo posterior que venga. Creo que ya habrá salido cierta antología de poetas norteamericanos contemp. Por Dios no te olvides de enviármelo todo. No admito ningún género de excusas, ni la de agotado. Por aquí quiero juzgar de tu amistad. Sois muy descuidados y malos amigos. No puedo entender cómo olvidáis enviarme todos esos tesoros. Quiero encua- 
dernar lujosamente la colección, y me encuentro con que me faltan mil cosas. Como sé que los encargos pueden dar al traste con tu felicidad, aquí pongo punto. A Genaro Estrada le envío el complemento de esta lista. Y a todos los fieles os pido que procuréis enviarme, bien certificado y empacado, todo eso: yo creo que podéis hacer una suscripción entre los amigos, y os saldrá a peseta por cabeza.

Procuraré escribirte aunque sea una vez al mes, y así te ruego que me contestes. No sabes la seguridad con que ando por la vida, respaldado de vuestro afecto y buena memoria.

Pronto recibirás un mal libro, o dos o tres. Ya veremos. Mil cosas tengo entre las manos, que irán una a una a las tuyas, como palomitas mensajeras. A Mariano un fuerte abrazo, y dos caricias: una para Carmen, otra para Clara; y una reverencia para su señora. Y tú, Julio, que aún me hablas de Eglantina, ¿en qué piensas? ¿Sabes de Acevedo, el Ingrato? ¿De Vasconcelos, el Díscolo? Cuéntame de todo y de todos, o no nos va a bastar el tiempo con sus ruedas de veinticuatro radios el día en que volvamos a encontrarnos.

Sabrás que Madrid comienza a tener unos días de niebla londinense: andamos con linternitas a medio día.

Alfonso

13 Febrero 1919, Madrid.

Julio hermano: acabo de recibir carta tuya. Estoy detrás de una mesa con faldas, bajo la cual hay un brasero encendido; sobre ella, mil diccionarios. Estoy uncido a una traducción por un mes. Da a Mariano y Sra. mi enhorabuena por la segunda nenita. Gran dolor fue para mí el saber que no estabais ya en París, como yo esperaba. Piensa que, para el verano, Pedro se instalará aquí definitivamente. Todo eso que me cuentas, yo lo adivinaba. Sólo me falta algo: algo de que nunca me hablas y de que yo no me acuerdo nunca al escribirte. Te enviaré mi retrato. Adiós, compadre, compadre de mi alma!

Alfonso

Mi gato se llama Pepe Bufa. ¿Qué razón me das de Juan Alvarez Gato? ¿Conservas aún mi calavera?

¡Oh Julio! 
Gracias, querido Julio. Gracias por lo que haces por mi suegro, gracias por el envío de las cuentas de marras, que al fin me llegaron. Gracias por tu carta, llena de promesas de primavera. Me hablas de tus lecturas: Conrad, Gide. Está bien. Pero ¿qué has escrito? No olvides que Poética espera con ansia tu colaboración. Pedro llegará de un día a otro. iSólo faltas tú! Por conducto de Genaro Estrada he mandado un librito para «Lectura Selecta» de González Guterrero. ¿Cuándo recibiré la Animula de Mariano? Feliz Navidad, feliz año.

14 dic 19. Madrid.

Alfonso

Madrid 11 Mayo 1920.

Julio mío: itu carta-poema! itu retrato en el grupo de la S. de E. M.! Todo me llega, menos tú, de paso para Grecia. Y en tanto, México, no hablemos. Y Pedro, Artemio tu paisano y yo paseamos por Extremadura y te echamos de menos. Di a Lectura Selecta que me manden ejs. de mi libro. Mándame tú mismo otro libro tuyo. Anda, ven, no tardes. ¿Qué haces? ¡Corren los días y los años, Julio! Sí: háblame siempre de las musas: les gusta mucho que hablen de ellas, yo las conozco bien.-Pedro ¡ay! vuelve a Minneápolis, sin haber podido adaptarse al clima y al mucho trabajo de España. Muy rendido, muy triste, vive como en sueños. Es desgarrador.

Tuyo

Alfonso

Madrid, 5 de julio de 1920.

Querido Julio mío de mi corazón:

Ya está tu carta en manos de Pedro; tu carta en que le hablas del famoso proyecto de Bibliotecas populares, y de los demás planes de «nosotros». Ya me contarás la suerte de vuestras campañas, y dime cómo y hasta dónde puedo yo ayudaros desde aquí en todo eso.

Ya supondrás que casi no lo quiero creer. ¿Tener yo seguro el sustento después de seis años de continua lucha e indecisión diaria? (Indecisión sobre si sería o no conveniente comer a medio día y cenar por la noche). No puedo creerlo, no. Tampoco es verdad (No puede serlo, no) que yo me voy de veraneo con mi mujer y mi hijo a los pueblos del Norte de España; 
eso no es cierto, yo estoy soñando, a mí me engañan, para que después fallezca de dolor. ¿Yo en Deva, yo en San Sebastián, yo en Zarauz, compitiendo en natación con Ortega y Gasset? ¿Yo en Zumaya? ¿Yo charlando académicamente a las orillas del Cantábrico, en Ondárroa, con mi queridísimo Canedo? No, Julio, no me hagas caso, a mí me pasa algo.

Ayer estuvimos en Alcalá y Guadalajara, Artemio, Pedro, mi hermano Alejandro y yo. Te mandamos un saludo. Siempre pensamos en ti. Te queremos mucho. Yo personalmente, soy feliz cuando recibo tus letras, y lamento que no te decidas a escribirme más a menudo. A escribirme y a «escribir». ¿Por qué no te mandan de compañero mío a esta Legación?

Saluda a toda la hermandad. (iAy, Julio, si supieras!... El Cantábrico es un mar que... Pero no, no es cierto: a mí me van a echar otra vez del puesto. Yo sueño, yo deliro. Yo creo que es un efecto del hambre atrasada).

General Pardiñas 32.

Tu Alfonso

Madrid, 15 de julio de 1920.

Querido Julio: Icaza me ha dejado ver tu última carta, y también una de Genaro Estrada. Escribidme también a mí, os lo ruego. Tengo encargo de pedirte algo para el semanario España, semanario de extrema izquierda escrito por nuestros amigos de aquí, de donde toma Núñinguez lo mío que reproduce en Rev. de Rev. No dejes de enviar, que eso da la sanción de Madrid. Ha muerto Cavia, y lo entierran esta tarde. Ha muerto Eugenia de Montijo, la mujer de Napoleón III, y también la entierran esta tarde. A la noche, tengo que ir a una cena que le dan a Mediz Bolio en el Liceo de América, una casa de juego disfrazada, donde él acaba de recitar unos versos en una velada cursi. Por aquí acaba de pasar, rumbo a México, un monstruo consular llamado Rip Rip. Artemio zumba chismes en torno de mi vida madrileña, antes tan viril y pacífica. Pobre Artemio. Yo me pregunto siempre en qué manos iré a quedar. ¿Por qué no habrán mandado acá a González Martínez? Pedro ha comenzado las compras de libros para las bibliotecas populares de la Univd., que has de forjar tú. Yo lo acompaño a todo, pues en ausencia de él yo me encargaré de seguir sus instrucciones, según un plan que ya él comunicará a Vasconcelos. Genaro dice que Vasconcelos me va a dar una comisión de la Universidad. Me alegro de antemano: será siempre mejor una cosa en que yo me gobierne solo, que una en que dependa del pobrecito de Icaza. Este 
llegó de México hecho una piltrafa; ahora, con una breve estancia en París, ha mejorado mucho; pero tiene mil y mil dificultades para que le paguen sus sueldos atrasados, que el ex Ministro Arredondo interrumpió porque le dio la gana, y el pobre hace rabias todos los días. Gracias que Mediz Bolio es hombre amable y dispuesto a complacerlo; si no habría en la Legación un pujilato diario. Querido Julio: está saliendo de las prensas un nuevo libro mío: El Plano Oblicuo. Lo he hecho yo por mi cuenta. Ojalá te guste. Pronto lo recibirás. Escríbeme largo, contándome muchas cosas, muchos hechos exteriores de esos que a ti no te importan y que a mí me hacen falta como a las bestias la alfalfa. Cuéntame de José, mi protector, y dile que quiero publicarle aquí un tomo gordo con todos sus ensayos juntos. Explícame por qué en este ir y venir de nombres no encuentro el de Guzmán. Y dime qué es de Castro Leal. Y oh Julio: protege y ayuda a la familia de mi suegro; si esas niñas saben escribir a máquina o algo, ayúdalas: haz que encuentren trabajo. Te lo suplico. Por las tardes, en este calor espantoso (pronto huiré de Madrid para veranear en el Norte) nos reunimos en la terraza del Regina, es decir, en la calle, todos los amigos; preside Valle Inclán con sus barbas grises, y suele venir Icaza a ocupar la diestra. Pedro nunca falta; Pedro para ahora en la Residencia de Estudiantes, y ha mejorado mucho: parece que el calor le sienta muy bien. Pero sus cartas síguelas dirigiendo a Pardiñas 32 y a mi cuidado, porque es lo más seguro, dados sus planes de viaje. Hace mucho que no tenemos noticias regulares de México. Tardan mucho, y como ahora dependo de allá, vivo inquieto. Ya supondrás que disfruto de la vida por primera vez desde hace seis años, y mucho más que entonces, porque algo he aprendido. Te estoy escribiendo muy de prisa, no me deja Artemio, que de tiempo en tiempo viene a fisgar lo que hago. No sé ni qué te he dicho. Adiós. Otra vez seré menos estúpido. Quise aprovechar un rato perdỉo. Saluda a toda la Hermandad. Dile a Genaro que ya recibí la información gráfica sobre Nervo, y el Sexto Sentido: que le agradezco mucho, y que me escriba como él sabe hacerlo: en línea desplegada. Lo supongo muy ocupado, pero él tiene mil cosas que decirme que a mí me interesa saber. Algunas me ha dejado ver Icaza, que naturalmente no tiene secretos conmigo. Adiós. Julio, adiós.

A José, a Mariano y a ti, mucho éxito en su Despacho. 
Madrid, 19 de julio torri de 1920.

Mi querido mes de Julio: No te alarmes. Esta página compuesta no es más que uno de tantos proyectos que Pedro y yo hemos hecho, y que aplazamos por ahora para estudiarlos mejor.

Quiero que le pidas a Mariano que me envíen directamente todas esas circulares etc. que Vasconcelos esparce a los cuatro vientos, y que yo recorto de los periódicos, para darlas a conocer aquí en pequeñas informaciones a la Prensa. Ya podían Uds. comunicarme regularmente notas sobre cosas de México que no sean la eterna política, para que yo las diera a mis amigos de los diarios. No lo eches en saco roto. Dile a Vasconcelos mi deseo. Yo quiero a toda costa colaborar desde acá con vosotros. Yo creo que la Universidad, para comunicaciones relativas a la vida «cultural» de México, hasta podía gastarse algo en cablegramas. Saludos fraternales y amenos. Sé feliz.

Alfonso

Madrid, 24 de diciembre de 1920.

Noche Buena, querido Julio, y no te tengo a mi lado, para compartir el pavo de Navidad. Por estos días, las calles se llenan de bandadas de pavos. Y el chico que los vende grita, elípticamente: «icebáos, cebáos!» (Pavos cebados). Y la gente se detiene, sonriente, a contemplar las dulces víctimas, atiborradas de nueces. iViva, viva el moco rojo y el trotecillo bamboleante en dos patas! Y viva la pipa de Navidad que me voy a fumar a tu salud esta misma tarde.

Por la noche, subiremos al primer piso -yo vivo en el bajo, pero un bajo con ventanas al descampado, lleno de luz-, donde cenaremos con unos vecinos daneses: una sobrina de Harald Hoffding, de regio aspecto y cuarenta y dos años escultóricamente cultivados. Unos niños con cara de apolos o bailarines rusos y cabelleras rubias «à faire rager le blé». Yo, naturalmente, hago el gasto del vino, y ellos el de la cocina: yo me presento de smoking, con una cesta en que alternan las botellas de Chateau Yquem, St. Emilion y Pommerie (¿se escribe así?). Hace mucho frío: arden las chimeneas. (Las chimeneas: yo soy un poeta de chimeneas. Las chimeneas me hipnotizan, y me consumen como a la leña seca. Yo me voy por las chimeneas. Ya no soy más que una hebra de humo en lo alto de un tejado de invierno... Ya no soy nada).

El buen Héctor Casasús acaba ahora mismo de cerrar la portezuela del 
auto, lo veo desde la ventana. Viene envuelto en pieles. Va a entrar. Hago una pausa. Aquí está.

Has hecho muy bien en suprimir las dedicatorias únicas de mi tomo de versos. No sé cómo me pasó eso: sin duda porque estaban allí puestas desde hace años, y no me atreví a tocarlas por debilidad de carácter. Después no he querido poner dedicatorias, porque serían falsas: artificiales. Yo creo que se debe dedicar lo que se escribió pensando en la persona, y nada más. En conjunto, todo lo escribo para mis amigos, ya lo saben todos. Lo que siento es que no te hayas decidido a suprimir algunas páginas que no te parecieran bien. Quizá hay mucho malo. Yo ya no tengo criterio para ese libro. Debes ayudarme tú. Tal vez ya es tarde. Tal vez ya ha salido al mundo a exponer mi vergïenza...

Me dices que me mandas un proyecto de notas sobre Huellas. No, por favor: publícala sin que yo la vea antes. Necesito, para orientarme yo mismo, tu opinión absolutamente sincera. En materia de versos soy la desorientación misma. Cada vez veo menos claro, y no me gusta nada, nada, de lo que hacen hoy por hoy nuestros poetas.

Me ofreces algo para España. Venga cuanto antes. A falta de mejor cosa, te envío aquí un retratículo, y espero el tuyo. Ya te enviaré uno de lujo cuando me retrate en regla.

Espero con ansia los libros de Genaro y Mariano, y te acompaño, in mente, en esos nuestros juzgados: «Oh, Julio, tú regresas al Juzgado,

a los juzgados de nuestras andanzas,

por donde fueron juntas

nuestras dos mocedades», como diría Fz. Ledesma.

Soy suscritor del Liberator iqué te habías creído!

Manuela y mi hijo te mandan saludar conmigo.

Un abrazo, y feliz año.

Alfonso

Madrid 29 mayo, 1922

Caro Julio:

Yo no puedo olvidar que cumples treinta y tres años en junio. Yo los llevo sobre el corazón.

Un abrazo

Alfonso 
Madrid, 27 de abril de 1923.

Mi querido Julio: Me ha causado mucha pena la tarjeta en que me dices lo que sucede con ese amigo nuestro. Todo me lo sospechaba, y es posible que si conservas mi correspondencia de otros años, encuentres ya entre mis palabras algunos amagos de queja, porque yo - temiendo siempre causaros la impresión de la deslealtad - me he estado conteniendo mucho. Pero de tiempo atrás vengo presenciando con pena ese desquiciamiento. Con todo, nada hay como la verdad para los corazones templados. Has hecho muy bien en decírmela, y te ruego que lo mismo hagas con todo, porque yo ya no sé lo que sucede, y tengo verdadero miedo de que otros hombres se me echen a perder. Cubramos este cadáver más con un manto de ceniza, y adelante.

Siento no tener bastante calma para escribirte hoy como debiera y quisiera, después de tan largo silencio. Yo te ofrezco hacerlo en cuanto tenga un instante de respiración. He pasado temporadas de ardiente trabajo en la Legación. Ama uno a su patria cuando está lejos: no hay medio de evitarlo. Ha habido, además, ciertas novedades en mi vida que hubiera querido comunicarte, mi fiel Julio, pero de las que no se habla por carta. Soy el mismo, lo mismo que tú. Así vamos.

La primavera coquetea en el cielo de Madrid. María Luisa de la Torre hace horrendas apreciaciones sobre Vasconcelos, aunque reconoce que lo mismo que está peleada con él podía ser su buena amiga, y a ti te recuerda con afecto. María Tubau está en cama, resfriada de representar «Retazo» con pies descalzos, entre las escobas de aire que barren los suelos de los escenarios madrileños. Tortillería y atrocidades. Esperanza Iris alterna el negocio con el alma (¿me entiendes?), y en su camerín me encuentro a Soledad Alvarez, la célebre «morronguita» de Enseñanza Libre que ignora tu adolescencia provinciana. Solita está ya envejecida, aunque todavía... y tiene una chica de catorce años, ya mujer por el cuerpo y cachondamente boba del alma, rubia como un pájaro que lo fuera, que irá a México a renovar las fechorías de su madre. Alli te espero: nos encontraremos en el ángulo de esa paralaje.

Adiós, Julio mío, mi leal verdadero. Dile cosas a Genaro, único con quien compartirás ¿qué digo el pan? el vino de esta cartísima.

Tuyérrimo fraterno y eterno, 


\section{Madrid 6 julio 1923.}

Julio inolvidable: Sí, tú tienes razón en desear cartas largas mías; pero yo también, tuyas. ¿No adviertes que tú sólo me escribes telegramasepigramas?

- Buscaré a tu metodista en el Centro de Est. Hist.

- ¿Por qué no escribes más libros? (¡Perdona esta salida estúpida!)

-Necesito que me describas tu vida, y las modificaciones de las leyes interplanetarias entre los amigos.

-Mucho te recuerda, en Madrid, León Sánchez y, en París, tu olvidado y adorante amigo Rafael Cabrera, que rehace nerviosamente su vida (joh, pequeños deberes incesantes de las Legaciones en París y en Madrid!) al dulce calor de los ojos —algo japoneses- de su esposa Merceditas. Escríbele: está muy solo, y teme siempre estar abandonado y hasta perseguido.

- Todos me dicen bien de ti, pero tú no me mandas el original de un libro tuyo, inédito y perfecto, para la biblioteca Indice, de Juan Ramón, más 300 pts. que te tocaría costear, más o menos.-Pronto recibirás mi Polifemo y $2 .^{a}$ ed. de Visión de Anáhuac.

-iMe dio tanto en qué pensar aquella tarjeta tuya! ¿Te acuerdas?

- Como notarás, no te escribo cartas largas por incongruencia mental. Epidemia de polilla o greguería de RAmón Gómez de la Serna.

- Entre tus bellas adiciones, al lado de Homero y Dante ;oh sorpresa! doy de manos a boca con el R. Rivera, el pobre viejito de Lagor. ¿Locura nacionalista? ¿Realmente vale algo ese libro? ¡Ay Julio!

-Dime: ¿hacemos sufrir mucho al gran Gordo sus amigos, con las mil chispas eléctricas de nuestra susceptibilidad diplomática? ¡Ay Julio! Abrázalo por mí, a ese grande hombre. iAsí fueran todos en nuestras tierras!

- Henry Béraud ataca a André Gide iqué animal! Y, al instante, el calambur de París:

C'est le martyre de l'obèse

devant la porte étroite!

Yo creo que Genaro vive en ese martirio. iAprendiera de mí a gobernar su panza!

-Escribo. Trabajo y peso y mido, y al rudo esfuerzo pido, etc. etc.

Acaso el verano acabe de dar brillo al metal (iqué digo, blasfemo!) acabe de sacar aristas a la piedra dura de mi Ifigenia cruel, entre cuyas piernas paralelas reposamos tú y yo, pobre náufragos del Paraíso.

Tuyo

Alfonso 
Madrid, 7 de diciembre de 1923.

Mi queridísimo Julio: ¡Cuánto bien me hacen tus cartas! ¡Cómo me rejuvenecen! Tú no puedes saber todavía lo que es este sentimiento celoso y receloso que, con los años, va dando de sí la nostalgia: una nostalgia díscola, que no quiere confesarse su verdadero nombre, que ni siquiera está segura de su identidad.

Sí: haces bien en renunciar a tu estrella de jacalón. Yo te confieso que aún no he aprendido a tener aventuras. Desde que dejamos de vernos, y sin abandonar mi cielo fundamental, he andado volando con mi aeroplano por varias atmósferas y temperaturas de distintos climas eróticos. Pero, Julio mío, siempre enamorado hasta el suicidio: nunca en fácil aventura; no sé. Soy una calamidad, y espero con ansia ese momento... ¡Pero no, qué diablo! Algunas veces he llegado a situaciones tan complicadas y extrañas que, cuando ya no haga sufrir a nadie con ellos, tengo que contarlas en una espléndida novela sentimental. La vida está llena de virginidades, y a cada paso, a poco que se descuide uno, da un tranco fuera de la calle habitual, y ya está uno en otra estrella.

Me resigno a que no me cuentes nada de esos líos en Educ. Pública. Genaro me remite a ti, y tú a la nada. Pero el mismo Pepe se ha apiadado un poco de mí, y me ha escrito y descrito algo, que yo trato de entrever por entre la cortina de llamas de sus ideas fijas de fanático apóstol. Me resigno, me resigno. iCon tal de que os encuentre a vosotros, cuando vuelva.-Estoy escribiendo un libro de versos, día a día, donde hay algo —no dedicado, no: no género: «A mi amada, para mi querido amigo don Fulano»- sino dirigido a ti, nominalmente.-Espero que te llegaría ya Los dos caminos. Ahora tengo ya en prensa la Ifigenia cruel y el Calendario. Pienso ponerme en cuerpo y alma a la Crónica de Monterrey y a $L a E S$ trella del Sur. De este modo, quedaré libre para los trabajos de mi quinta manera, que viven ya dentro de mí. Dime, Julio: ¿es cierto, como comienza a parecérmelo, que ya los muchachos de los últimos barcos no me estiman? Alguno hasta dice que no soy mexicano: ¿y Nervo sí lo era? Porque Nervo vivió más que yo fuera de México y conservó menos que yo sus ligas con su generación. ¿O es que hay que fracasar en el extranjero para ser buen mexicano? Dime tu opinión sobre este puntillo de honra, que a ratos, comienza a inquietarme.

Te ruego que me envíes el libro de Best sobre dibujo mexicano, y también esa coleccioncita popular en que está lo de Juan Hidalgo. Me agrada seguir todo lo de México, pero particularmente aquello en que tú has puesto los ojos. 
Dile a don Francisco de Icaza que lo amo y recuerdo afectuosamente. He tenido ocasión varias veces de ver a su familia, la cual está convencida de que a don Francisco va a ser preciso arrancarle de México por la fuerza, pues de lo contrario no vuelve por acá. Yo recibí cierto telegrama suyo, pero su señora me dijo que ya no tenía objeto mi intervención en ese asunto, que ya estaba arreglado (lo del Médico).

Una piadosa mano anónima mandó a Cipriano Rivas Cherif - ya sé quién fue- todos los recortes adversos a don Francisco. Cipriano me preguntó de qué se trataba, y yo le di una idea ligera del asunto, pero justa. El, que es escritor de tipo «meterse con», hizo una notita en el semanario España en la que, para defender a Don Francisco, se creyó obligado a atacar a Paso y Troncoso (jestos errores de la pasión!). Y ahora resulta que Pereyra publica en España una carta en que vuelve por la honra de Paso y Troncoso, pero de paso, y algo más en las líneas que entre líneas, deja ver cosas que declaran su opinión adversa a don Francisco en el asunto ese tan molesto. Creo que es preferible que los amigos hagáis porque no lo vea don Francisco; pues, tratándose del esposo de María Enriqueta, las declaraciones son graves.

Me da pena insistir, pero yo debo decirte que vivo esperando tus nuevos libros. Además, me debes enviar lo más pronto posible, para mi colección de «Cuadernos Literarios», lo que tengas: ha de hacer un tomo menor que en $8 .^{\circ}$, de unas 100 págs. Nada más. No te costará trabajo: reúne todo eso, y mándamelo a vuelta de correo. Ya viste que Juan Ramón ha hecho reproducir cosas tuyas en España. No coquetees así con la gloria. Mira que un día seremos viejos. Mira que...

Yo estoy muy inquieto por las noticias de México que trae la prensa de hoy. Las rectificaciones oficiales, que me llegaron hoy con gran oportunidad, son algo anteriores a las últimas noticias. ¿Qué habrá pasado para cuando ésta te llegue? Fiemos en la estrella.

También me harás favor de insistir junto a Genaro Estrada para que me mande un «cuaderno literario». A Pedro ya se lo pido. Dime a quién más se le puede pedir. ¿Nos mandaría algo inédito Vasconcelos? ¿O me dejaría a mí escoger aquí cien páginas misceláneas de lo mejor que haya hecho? Pregúntaselo, s.v.p.

Adiós. Se me echa encima el trabajo, y ya no estoy con el ánimo tranquilo para escribirte. Pronto seguiré.

Un abrazo

Manuela y tu discípulo te saludan.

Alfonso 
